\title{
痴呆性高齢者グループホームの環境及び入居者の固有の居場所と その変容に関古る研究 \\ ENVIRONMENT AND RESIDENT INDIVIDUAL'S 'PARTICULAR PLACE' \\ AND CHANGE OF IT IN A GROUP LIVING FOR PEOPLE WITH DEMENTIA BASED ON CONSECUTIVE RESEARCH
}

\author{
山田あすか*，上野淳** \\ Asuka YAMADA and Jun UENO
}

\begin{abstract}
This paper aimed to deepen the consideration of our previous paper about the environment of group living and the selection of individual resident's 'Particular Place,' based on the results of a series of five researches conducted once a year through 4 years. Consequently we gained the knowledge as follows; 1) The residents leave GH (the group home) in a little less than one and a half years on the average although the period of time considerably varies. During their stay in $\mathrm{GH}$, their ADL (activities of daily living) and dementia gradually deteriorate. 2) The change of residents by entering and leaving and that of residents' ADL or dementia level cause frequent transforming of interpersonal relationship and room allotting in GH. 3) Each resident has a 'Particular Place' or some 'Particular Places' which are more meaningful than other places for themselves. Although 'Particular Places' are often situated at common spaces, each of them is to be said to be selected by each resident influenced by various environmental elements. 4) The number of 'Particular Places' of a resident and the rate at which some element becomes the factor of the selection of 'Particular Place' have a certain relation to residents' ADL or dementia level. 5) The changes are seen in 'Particular Places' and the aspects of being there for long-term residents in the GH. The transformation in the settings, interpersonal relationship, and attributes of residents strongly influence those changes. Above all, interpersonal relationship is influential in both of the selection of 'Particular Place' and the aspects of being there.
\end{abstract}

Keywords : The elderly with dementia, Group living for the elderly, The particular place for a person, Aspect of being there

痴呆性高粈者, グループホーム, 固有の居場所, 居方

\section{1. 研究の背景と目的}

1. 1 社会的背景 痴呆性高齢者の増加が大きな社会問題となっ

ている. 要介護 1 以上の高齢者 380 万人の約半数, 182 万人が何らか の痴呆を有し，うち147万人以上が日常生活において介護を必要とす る自立度 II 以上註1) だとされる（2004年 2 月末，厚生労衝省）。疾呆 性高齢者は 2010 年には 200 万人を，2025年には 300 万人を越えると 予想される，痴呆性高齢者ケアの切り札として，痴呆性高齢者グルー プホーム（以下；GH）が1995年前後に日本に紹介された。 GHは 2000年施行の介護保険で制度の一つに採用され，急速に増加してい る註2). GHは少人数で家庭的な環境の中で, 痴呆を持つ入居者がで きる範囲で家事を分担しつつ共同生活を営むことを基本理念にしてい る.このためGHは他の高齢者入所施設に比べ，入居者が生活に主体 的に関わる, 入居者同士や職員との関係が濃く密度高いヶアができ る, などの特徴を持つと言える.こうしたGHでの生活が痴呆の進行 や身体機能低下の緩和に効果があると期待されている.

1.2 理論的背景 GHの增加に伴い, GHの平面形態や計画動 向の整理, 観察調査によるGHにおける痴呆性高齢者の生活像やその 変容の呈示文 $1-10)$ ，など建築分野でも GHに関する様々な研究が行わ れてきた，筆者らは，既報文1) で入居者個々人の居場所と居方に着目 し， 1 年間をおいた 2 回の調査を元に, 居場所の構成要素の把握と,
その居場所の本人にとつての意味の解明を試みた。ここでいう居場所 とは, 壁や床, 家具などの物理的要素, 職員や他の入居者の人的要 素, 入居者の生活背景, 現在の生活の文脈や本人の思い入れなどの個 人的要素を含む概念である. 前稿では, 以下の知見を報告した.

1) 痴呆の程度によらず, 入居者は本人にとって他の場所よりも意味 合いの強い「固有の居場所」を持つ.

2 ）入居者は, GH内の場所の物理的・人的要素に対し個々人の個人 的要素によって意味付け，その場所を固有の居場所として選択する.

3) GHの環境は入居者の入退居や居室の変更などにより変化する.

4) 入居者の痴呆度やADLなどの属性は刻々と変化する.

5 ）そのため, 入居者の固有の居場所の選択もまた変容していく.

1.3 本稿の目的 痴呆性高齢者は今後さらなる増加が予想さ れ，そのケア環境について一層議論を深める必要がある. 個々の入居 者が生活の拠点となる固有の居場所を持つことは, 居住施設が入居者 個々人の生活の場となる上で重要と考える，それゆえ，固有の居場所 の選択要因の解明は，個々の生活やその集合としての共同生活の舞台 となるGHを計画する上で有効と考える. 筆者は, 前稿で得られた知 見に基づき $\mathrm{GH}$ 環境の変化とその中での入居者の固有の居場所の変 容に着目し，前稿で取り上げたGHで毎年 1 回，4年間で計 5 回の継 続的な調査を行った。本稿ではこの結果をもとに, 以下 3 段階により
* 首都大学東京 大学院工学研究科建築学専攻 日本学術振興会特別研究員 (PD) - 博士 (工学)

** 首都大学東京 大学院工学研究科建築学専政 教授・工博
Division of Arch., Graduate School of Engineering, Tokyo Metropolitan University, Research Fellow of the Japan Society for the Promotion of Science, Dr. Eng. Prof., School of Architecture, Tokyo Metropolitan University, Dr. Eng. 


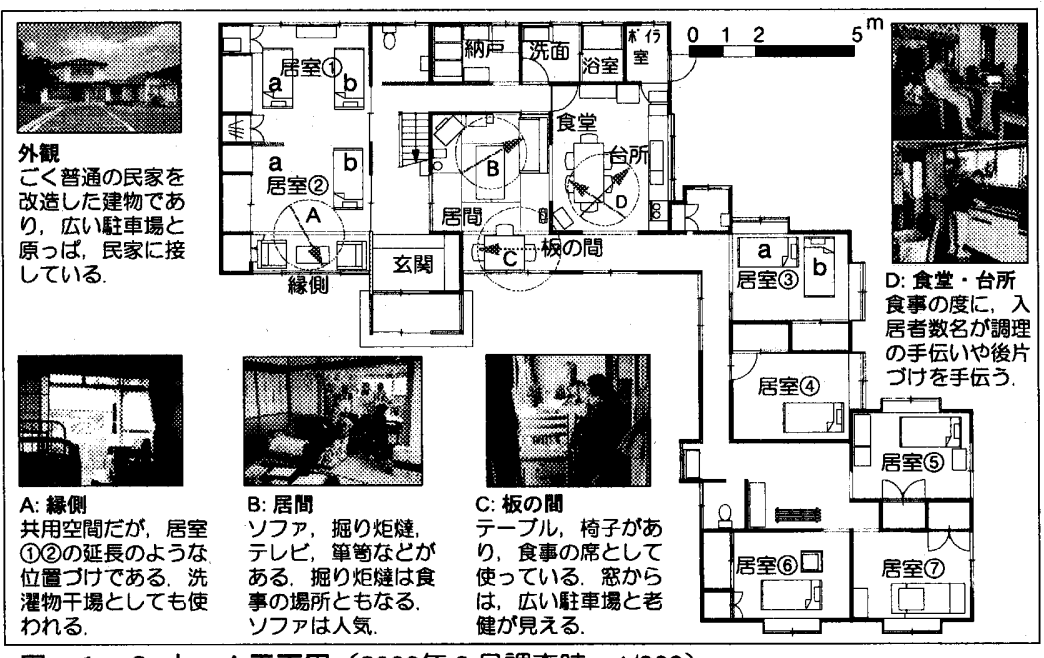

図・1 Saホーム平面图（2000年 8 月調査時, 1/300）

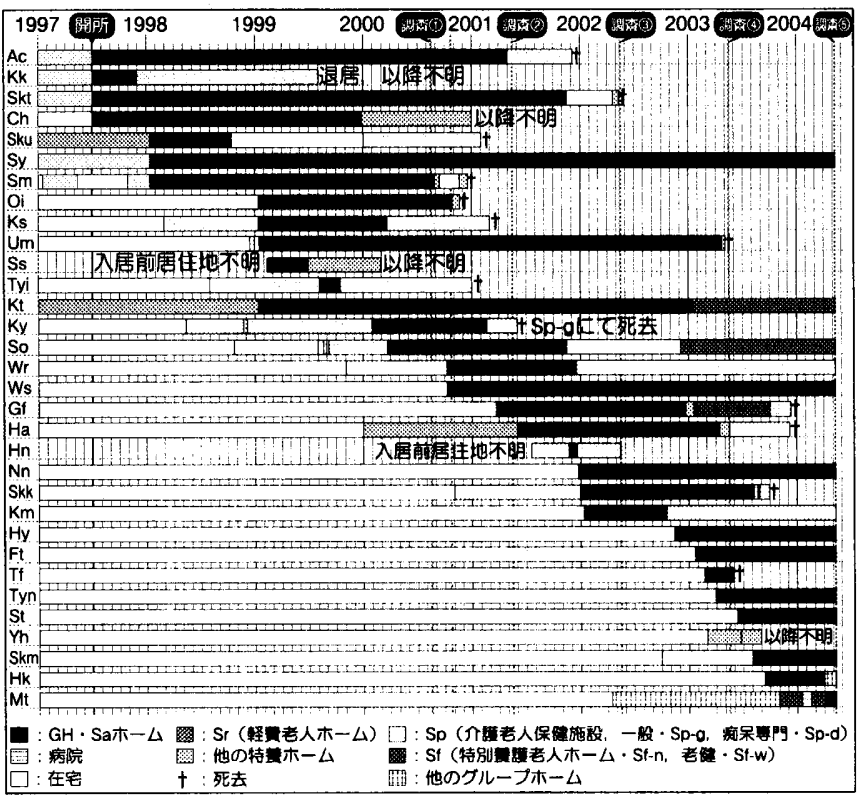

図・2 Saホーム開所からの入居者の变遷 (入居者の順は, 入居順による)

GHの環境と入居者の固有の居場所選択について考祭を哚めることを 目的とする. (1)変容していくものとしてのGHの環境の奉態の総括. (2)その中での入居者の固有の居場所の選択とその要因，及び前稿では 不十分であった固有の居場所と痴呆度やADLなどの入居者の属性々 の関係の分析. (3)固有の居場所の経時的な变容と之の要因の解明.

また本研究は，民家改修型であるなどの個別の条件を持つGHを対 象としたものであるが，固有の居場所の抽出やその変容の要因の分析 といった方法論は，一般論としても敷衍しうるものと考える.

\section{2. 調查方法と調查の概要}

2. 1 調查対象施設概要 調査対象とした Sa ホームは老人保健 施設を母体とし，1997 年に既存の民家を改修して開設した $\mathrm{GH}$ であ る.開設当初の定員は 6 名であったが，1999年に居室を増築し，定 員は 9 名に増光た. 居室は 7 室で, 居室(1)〜(3)のうちの 2 部屋が 2 人 部屋となる。職員は私服で，地元言葉の敬語を用い，サポート面でも 家庭的な雾囲気である。図・1，表・1に，Saホームの概要を示す。

2 . 2 調查概要 調査は $2000 \sim 2004$ 年に年 1 回で計 5 回，延 ベ24日間にわたり行った（表・2）。調査は参与観察集3)を基本とし， 調查員が入居者と生活を共にしながらホームでの生活を詳細に記録す
表・ 1 調査施設概要

\begin{tabular}{|c|c|c|c|}
\hline 星区分 & グループホーム & 開所 & 1997年 7月 \\
\hline X嫦主体 & 社会福祉法人 & 所在地 & 山形県米沢市 \\
\hline 定骨 & $\begin{array}{l}9 \text { 名 (1999年より, 増 } \\
\text { 築による. 䦎所時 } 6 \text { 名) }\end{array}$ & 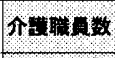 & （日名勤 3名，夜間 1 名） \\
\hline 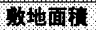 & $1239 \mathrm{~m}^{2}$ & 延床面棈 & $185 m^{2}$ (1 階のみ) \\
\hline 対象 & \multicolumn{3}{|c|}{ 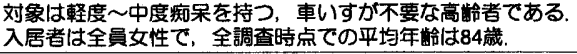 } \\
\hline 并設施設 & \multicolumn{3}{|c|}{ 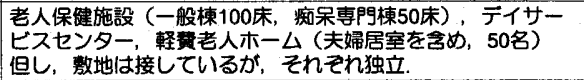 } \\
\hline 特的 & \multicolumn{3}{|c|}{ 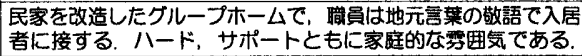 } \\
\hline
\end{tabular}

表・ 2 調査概要

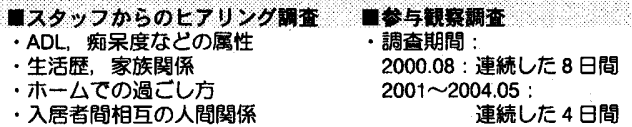

連続した 4 日間

ホーム内の設え ・調查時間 : $5: 00 \sim 22: 00$

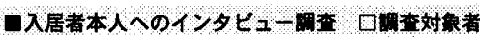
$\begin{array}{ll}\text { 生活歴思いやこたわり } & \text { 調查時の入居者全員で, 総数228 } \\ \text { 日頃の名 } & \text { 延べ48. }\end{array}$

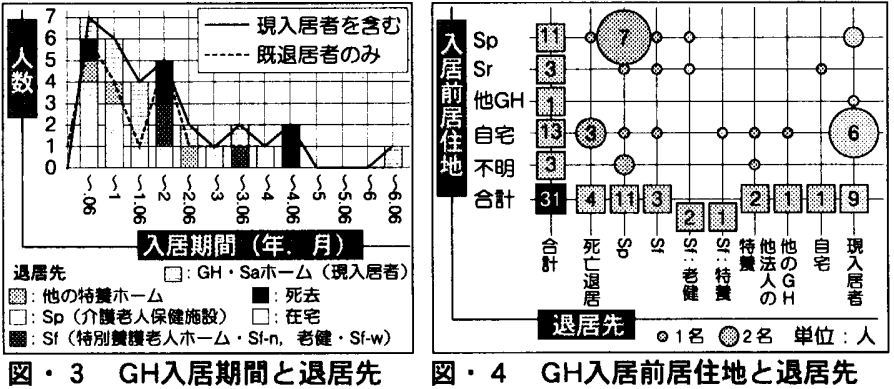

るとともに,会話の中から日々の思いや場所への愛着などを聞き取っ た.さらに入居者へのインタビュー, 職員からのヒアリング調査を行 い，入居者の内面，過去及び現在の状況に関する情報も収集した，

3. $\mathrm{GH}$ の物理的・人的環境の移り変わり

3. $1 \mathrm{Sa}$ ホーム開所からの入居者の移り変わり（図・2）

1) 入居期間（図・3） Saホーム開所から 2004 年 5 月までの退 居者は 22 名である被4). 平均入居期間は 1 年半強だが入居期間には幅 があり, 入居後 1 ケ月で退居する入居者もいれば， 6 年半以上入居し ている入居者もいる，入居後 1 年以内に退居した 10 名（45\%）のう ち4名は GHになじめず 5 ケ月以内という短期間で退居した。

2) $\mathrm{GH}$ 入居前と退居後の居住地（図・4）現入居者を含むこれま での入居者 31 名の入居前居住地は, 自宅 13 名，母体施設であり併設 されている老健 11 名，同じく併設の軽費老人ホーム 3 名である．開 所当初は母体施設からの入居者が多かったが, 近年の入居者は殆どが 自宅からの入居である（図・2）。この傾向の背景には，ここ数年で の $\mathrm{GH}$ の認知の広まりがあると思われる. また退居先は, 短期の入院 を含む死亡退居 4 名，老健施設 13 名，特養 3 名，他，である

3) 退居の理由 まず，退居の要因となるGHの事情を以下にまと める. (1)夜間 1 名の勤務態勢で医師・看護師の当直がなく，常時また は緊急時に看護を提供できない. (2)民家改修型のGHであるため主に 廊下幅の問題から車いすの使用が困難である，家庭浴槽のためADL が低下した場合は入浴介助が問題となる. (3)職員数の限界から, 重篤 な介護が必要な入居者のために他入居者へのケアが薄くなる懸念も あって，ADLが極端に低下した場合の継続居住は困難である。

次に, 入居者の退居の理由を $\mathrm{ADL}$ 不適切, 車いす使用, 体調不良, 精神不安定, 他入居者とのトラブル，その他，の6項目に分けて図示 した（図・5）。既退居者 22 名の退居理由は，死亡退居を含む体調不 
良が 13 名と最も多い. また，他入居者とのトラブルにより退居した 7 名のうち 6 名が精神不安定であり, 入居者の精神状態の不安定化が 他に与える影響は大きいと推察される. その他の理由では, 特養や自 宅に近いホームに移るなど家族の事情が目立つ.こうした入居者の入 退居により $\mathrm{GH}$ 全体の $\mathrm{ADL}$ や痴呆度, 要介護度は結果として一定の 水準に保たれている.このような入退居のシステムを支えるのは, 重 篤な介護が必要な入居者の退居先となる母体施設の存在である。ま た，既退居者で退居後の状況が分かる19名のうち 14 名はすでに死亡 しており, うち 11 名は退居後 2 年以内に亡くなっている(図・6). 3. 2 入居者のADL と痴呆度およびその変化社5) (図・7, 図・8)

入居者のADLは平均 68 である。一部介助を要する場合もあるが, 基本的に歩行や摄食は自立している. ADLは，入居後一時的に高くな る入居者もいるが，次第に低下する，また，入居後 1 年目前後に ADLが低下する入居者が多い. GH内では殆ど動かず，運動不足がち な入居者が多いことも一因と考えられる，当該GHは豪雪地帯にあ り，外出が困難な冬場にADLが低下しやすいという，ADLが30を下 回ると, 設備や他入居者との関係などの問題で, このGHの生活には 適さなくなる. 痴呆度 I $\mathrm{a} \sim \mathbb{I} \mathrm{b}$ b入居者が多く, N以上の入居者は 少ない，また，稀に痴呆が殆どない入居者もいる，痴呆がMの段階に なると，このGHでは対応が困難になる. 全体として痴呆は稳やかに 進行するか殆ど変化が見られないかで, 痴呆が劇的に進むことは稀だ が，ADLと同様入居後 1 年目までに痴呆が進む例が少なくない.

3. 3 入居者の入退居, $\mathrm{ADL} \cdot$ 痴呆度の変化による人間関係の変化 GHでの生活は小人数で営まれるため, GH内の人間関係は非常に 濃いものとなる註 6$)$. 痴呆が I 〜 II程度で他者との関係を持てる入居 者が多く, 入居者の対人的な性格や入居者同士の相性によってGH内 の人間関係は穏やかな好ましいものとも，その逆ともなりうる。

1 ) 他の入居者との関わり方 入居者同士の人間関係や入居者の対 人的な性格についての職員からのヒアリングと観察調査を元に, GH 内の人間関係の相関図を作成した（図・9）. 図中実線は「話しかけ る・近くに寄っていく」などの好意, 点線は「悪く言う・不満を持っ ている・近くには行かない」などの非好意を示す，図より，入居者の 他者との関わり方には，図・10に示す 5 つのパターンがあるといえ る. ある入居者がいずれのタイプに属するかは, その入居者の生活歴 や性格, ADLや痴呆度, 他の入居者との相性などの諸条件により, 一定のタイプに固定されるものではない，例えば，Ktは00年調査時 にはタイプ(5だったが，次第に痴呆が進み 01 年調査時には周囲に対 し好意・非好意を示すことは減った，また，Wsは01年調査時には夕 イプ(2)だったが，仲の良い入居者が退居したのち，新しい入居者とは うち解けられず，03年調查時にはタイプ(4)となっていた.

2 ) GH内の人間関係 GH内の人間関倸は, 入居者の属性の変化 や入退居, 他の入居者との関わり方の変化に伴って変容していく. 仲 の良い入居者が退居する $(\mathrm{Skt00 \rightarrow 01)}$, ソリの合わない入居者が

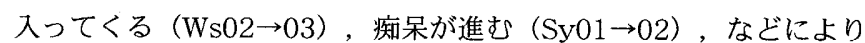
人間関係の中で孤立してしまう例や，新しい入居者之意気投合し毎日 機嫌良く暮らせるようになる（Kt00 $\rightarrow 01 ）$ 例などがあった．人間関 係が構築される上で特に「話ができる」ことは重要で, 話し相手に なってくれる人に親しみを持つ入居者が多い.テーブルの上に置かれ た花や新聞，空の外の風景について時に職員を交えて入居者らが会話 をする場面が多く見られ，これらは人間関係構筑の一助となっている と考えられる. 一方痴呆が重く会話が困難な入居者は, 共用空間で職 員や他の入居者となんとなく居合わせる中で人間関係を構築している ことが多い．またGH内には他者からの非好意の対象となる入居者が 常に 1 人はおり，トラブルが一切ないということはない。痴呆が重い ため周囲に合わせず自分の思い込みを話し続ける入居者（Km02，

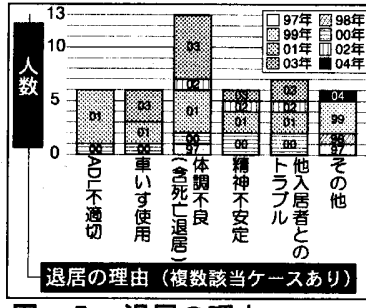

図・5 退居の理由

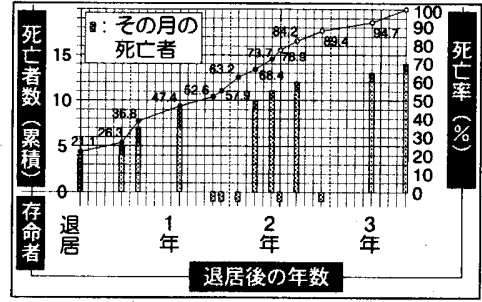

图・6 退居後の死亡率

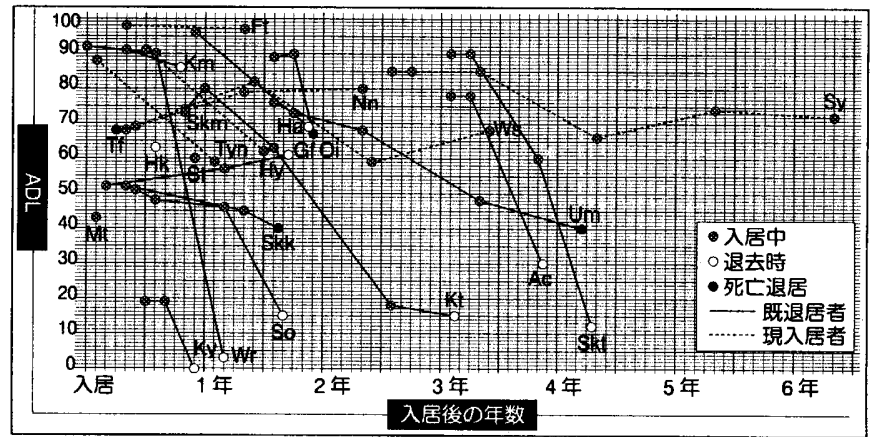

図・7 各入居者別ADLの推移

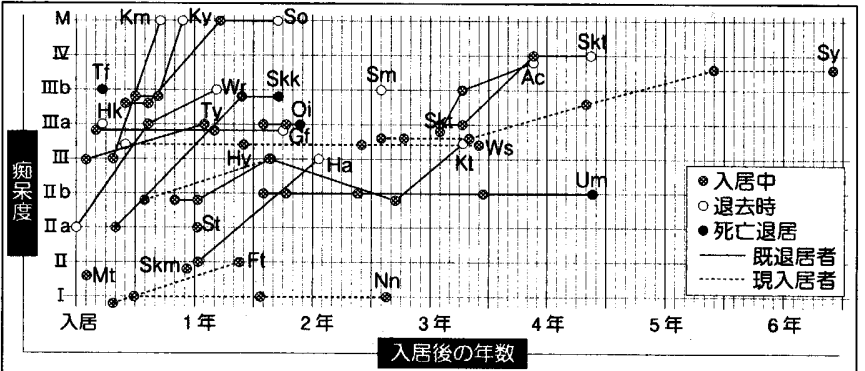

図・8 各入居者別痴呆度の推移

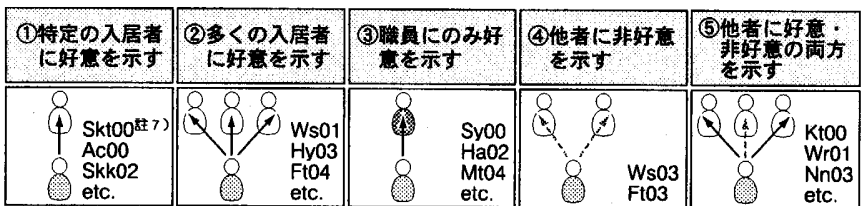

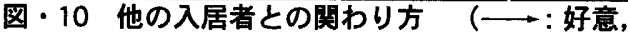

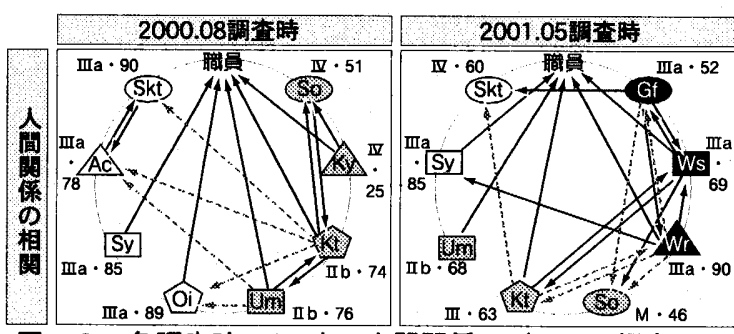

図・9 各調査時のGH内の人間関係
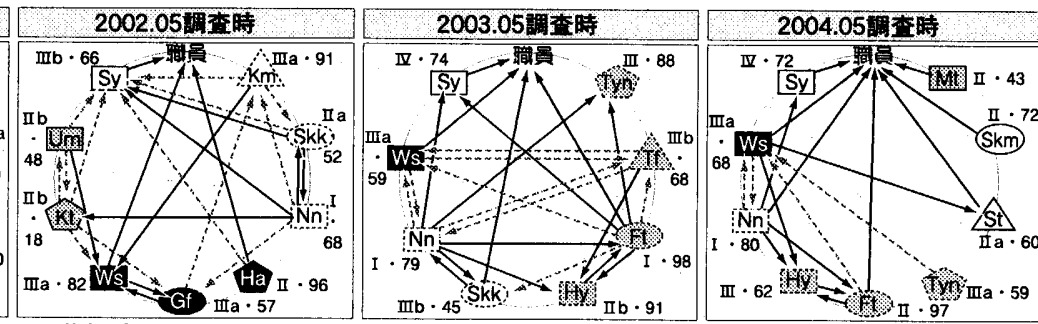

非好意，入居者の位逼は入居順て，時計回りと逆に入居期間が長い，入居者の記号は，入居者の別を示す） 
Ws03, Tf03, etc.）や, 痴呆が重く非䧃し続け，他からの会話に応え られない入居者（So01，Sy02）は非好意の対象となることが多い.

3.4 居室の変化 $\mathrm{GH}$ 開所からの居室の変遷を図・11にまとめ た. 居室変更の主な理由は, 入居者の入退居, 体調不良, 精神状態の 不安定化,である.このGHは空間の構成から, 居室(1)(2)(3)職員が 居る台所・食堂・居間から見通しやすく, 居室(4)〜(7)は逆に見守りが しにくい，このため，居室(1)（3)は入居後間もない入居者や体調や精 神状態が不安定な入居者の居室とし, 居室(4)〜(7)は比較的自立度が高 く見守りの必要があまりない入居者の居室とするなど配慮している. このため居室(1)〜(3)では小刻みな居室変更が多く，居室(4)〜(7)の居住 期間は比較的長い。また，居室(1)～(3)は個室としても多床室としても 使用しているが，個室では夜間落ち着かなかった入居者が多床室にな ると落ち着いて眠れるという例が多かった，入居者同士のマッチング に充分に配慮し居室配置をしているこのGHでは，多床室の存在が見 守りや入居者の落ち着きの面でもうまく作用しているようである.

3. 5 設えの変化 食堂, 居間, 板の間の 3 つの共用空間は, 間 の戸が取り払われ空間が壁で分節されながらも連続している.どこか に居れば他の入居者や職員の存在が意識され，共用空間では他の入居 者から完全に距離をおくことはできず，入居者同土のトラブルを避け るため職員が入居者の誘遒を行うことがある．特に食事の際には，入 居者同士のマッチングに配慮し職員が入居者の席をある程度誘導して いる，当初，板の間と食堂の 2 つが食事の席だったが，02年 1 月に 居間のテーブルを掘り炬燵とし食事の席とした。03年 5 月の調査時 のみ，居間のソファが板の間に置かれ，板の間のテーブルは居室(1)に 置かれた。現在では共用空間の食事の場が食堂, 板の間, 居間の 3 つ になったため，入居者のマッチングの調整は多少容易になった．居室 (1)(2)と縁側は，居室変更が多いためもあって，頻繁に設えが変わる，

\section{4. 入居者の固有の居場所と固有の居場所の選択要因}

4. 1 固有の居場所の定戔 入居者の居場所の展開はそれぞれ場 所や滞在時間，移動の回数の点で異なるが，個々の入居者に滞在頻度 や滞在時間，その場所での行為に特徴を持つ居場所が存在する义゙11 このような特徵を持つ居場所には，本人にとって何らかの意味がある と考えられる. 本稿では，入居者一人ひとりの個々の居場所が，
1 ）滞在頻度が他の場所よりも明らかに高い

2 ）滞在時間の合計が他の場所よりも明らかに多い

3 ）その場所と結びついた行為や発話がある

4）日々の生活の中で繰り返しその場所を選択している という項目に一つ以上合致する時, 個々の入居者の「固有の居場所」 と表現する. 入居者と生活を共にする数日間・終日の参与観察の結果 から，条件に基づき個々の入居者に $2 \sim 5$ 程度の固有の居場所を抽出 した. 図・12に, 計 5 回の調查時の全入居者のべ42名の固有の居場 所，157箇所を一覧で示した. 前稿では，個々の入居者が固有の居場 所を持つことを発見し，入居者本人にとっての固有の居場所の意味を 読み解く手法を試論として示した。本稿ではその後の調査で得た多く のデータから, 改めて入居者の固有の居場所について分析を行った.

4. 2 固有の居場所選択の要因 同じ場所を居場所としている場 合でも，相手の有無など周囲の状況や姿勢，行為，心理状態などの居 方部8) は個々の入居者によって異なる．入居者による固有の居場所選 択の要因を分析するため，それぞれの固有の居場所を「場所（柱や壁 などの建築的要素，そこからの景観，家具などの設え）・もの（ぬい ぐるみ, 鉢植え, 台所の調理器具など, 動かせるもの)」の物理的要 素,「職員・他の入居者」の人的要素,「（そこで行っている）行 為, 状態」の個人的要素に分けて整理した，さらに，入居者の居方や 本人・職員からのヒアリングを手がかりに固有の居場所選択の要因と なっている要素を抽出した（図・12ab右）湔9)，例えば図・12aの最 上段のSk00「食堂のテーブル」の事例は［職員の声かけで自室から 出てきて, Acの声かけで食堂のテーブルの席に着き, 食事を待ちつ つAcと会話をする，食事が終わるとすぐ自室に帰る]と記述され る.ここでは「他の入居者・行為」が居場所の選択に影響していると 解釈した. ここで特に, 眠る，ぼんやりする，などの消極的行為と， 他の入居者と会話する，新聞を読む，などの積極的行為は明らかに フェーズが異なるため，図中では別色で表現している，また「自室の ベッドで，眠るだけ」という固有の居場所は，他の居場所に比べ重要 度が低い目10) と考え，以降の分析ではこれらを除いた。

4. 3 固有の居場所となる場所次に, 固有の居場所を場所別に 集計した（図・13円グラフ）。固有の居場所となる頻度は共用空間

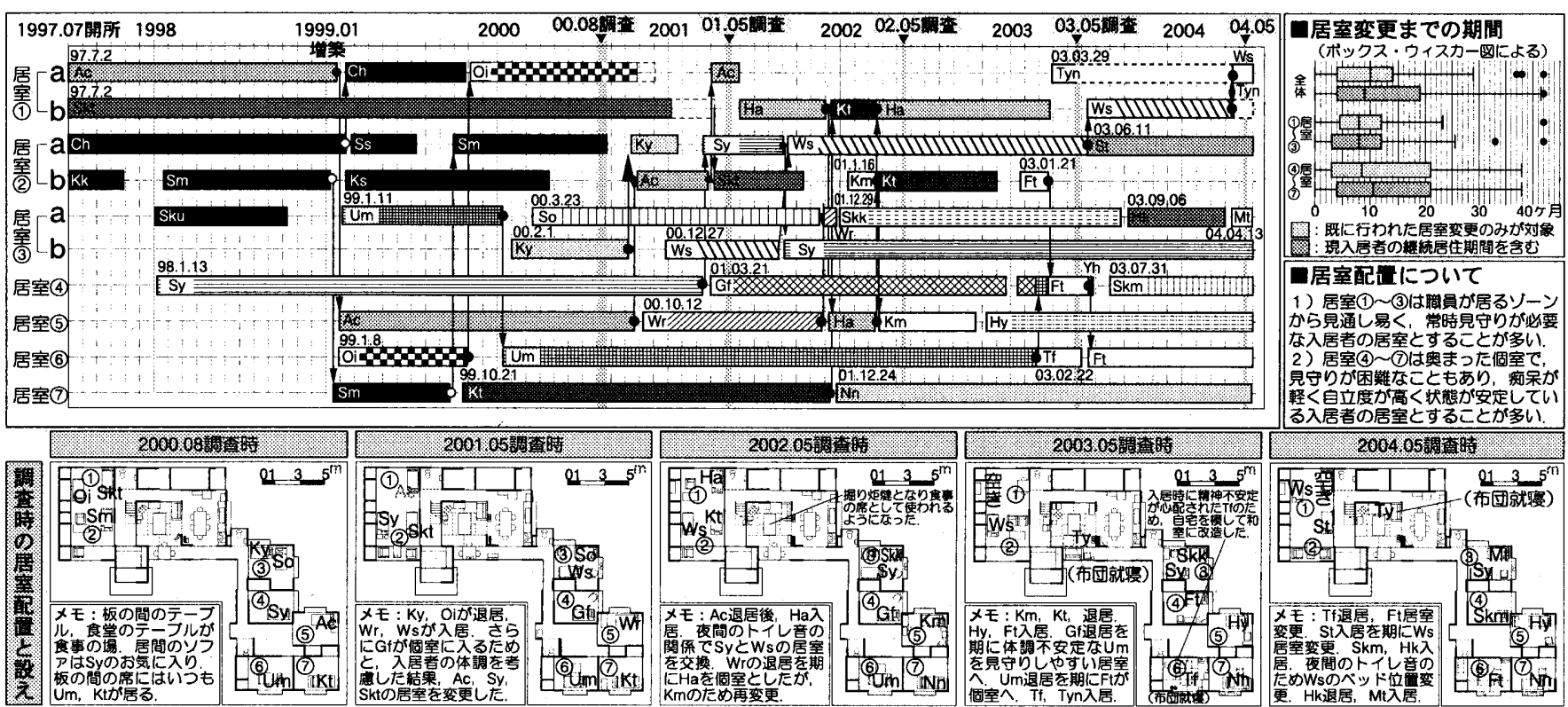

図・11 開所時からの入居者の入退所と居室の変遷 （1 スパン=1ケ月，図中の日付は入居日，初期入居者は黒で表現） 


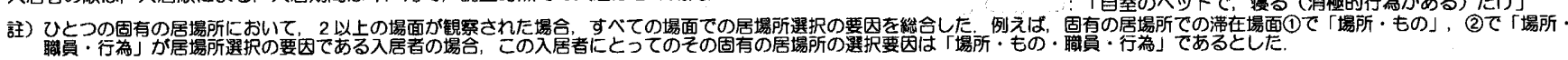


が最も多く, ついで自室, 他の入居者の居室, 半共用空間竐11) の順と なる. 共用空間では, 食堂のテーブル, 板の間のテーブル, 居間・板 の間のソファの割合が高い。図・12ab右の, 場面の構成要素のうち 入居者の居場所選択に係わる要素を, それぞれの場所ごと, 要素ごと に集計し，各要素が固有の居場所選択の要因であった割合を求めた （図・13表）。ここから, 居間のテーブルは「職員・行為」, 台所 は「場所・もの・行為」が居場所選択の要因となるなど，それぞれの 場所の入居者にとっての意味の違いが分かる．テーブルの「固有の居 場所」は食事の席でもあることが多く, 食事の場所にそのまま滞在す る，食事を待つ，など日常的な行為が固有の居場所選択のきっかけに なっていると言える，また，仲の良い入居者の居空でおしゃべりす
る，居間のソファでなんとなくテレビや職員が働いている様子を見な がらゆっくりする, 自室と連続する半共用空間のソファに座り外を眺 める，などの場面も見られ，「お気に入りのソファがある」「仲の良 い入居者が居る」「職員の姿が見える」「自室（の延長）と感じる」 など何がしかその場所に行く理由やきっかけがあることが, 固有の居 場所選択の重要な要因であると推察される。

\section{4 入居者の属性と固有の居場所及びその選択要因の関係}

入居者の痴呆度及びADLと固有の居場所数及び居場所選択の要因 数との関係を図・14に示した. 固有の居場所の数と痴呆度との間に 有意な相関は見られないが, ADLが高いほど固有の居場所の数が多 い傾向がある. 固有の居場所選択の要因となる要素の数は, 痴呆が軽

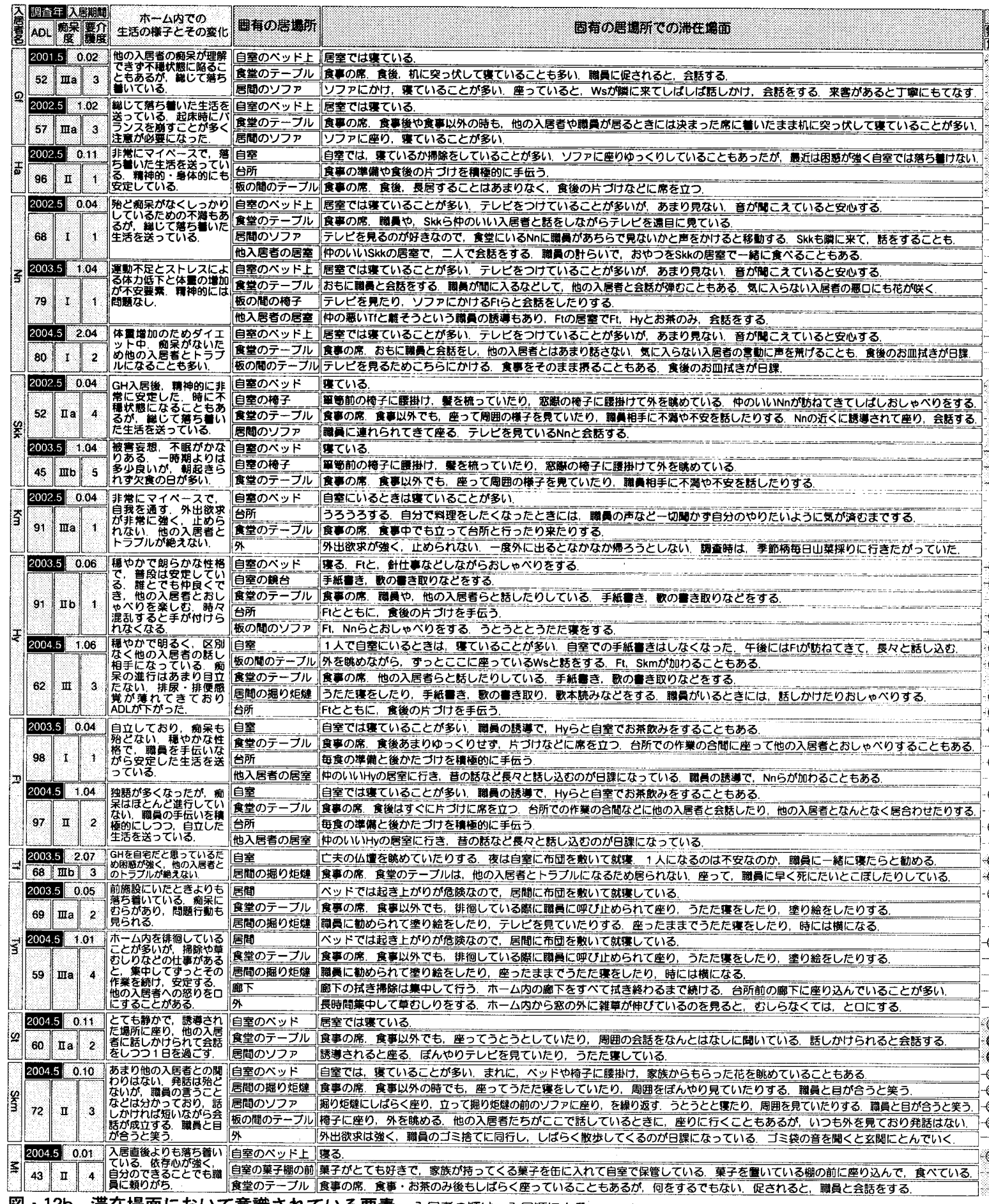

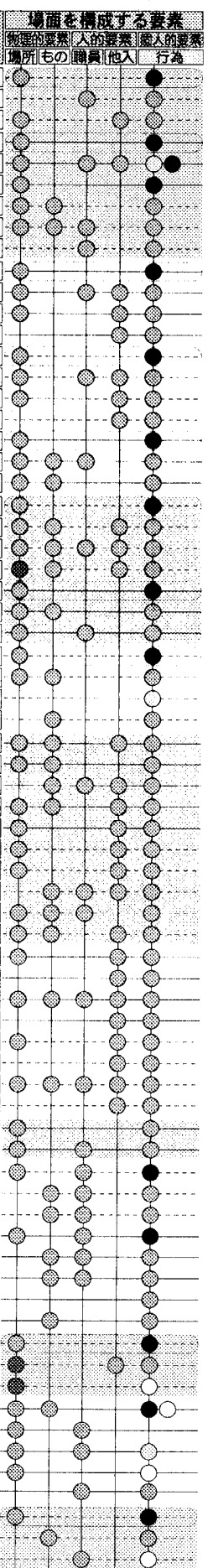

: 居場所選択に係わる要素 

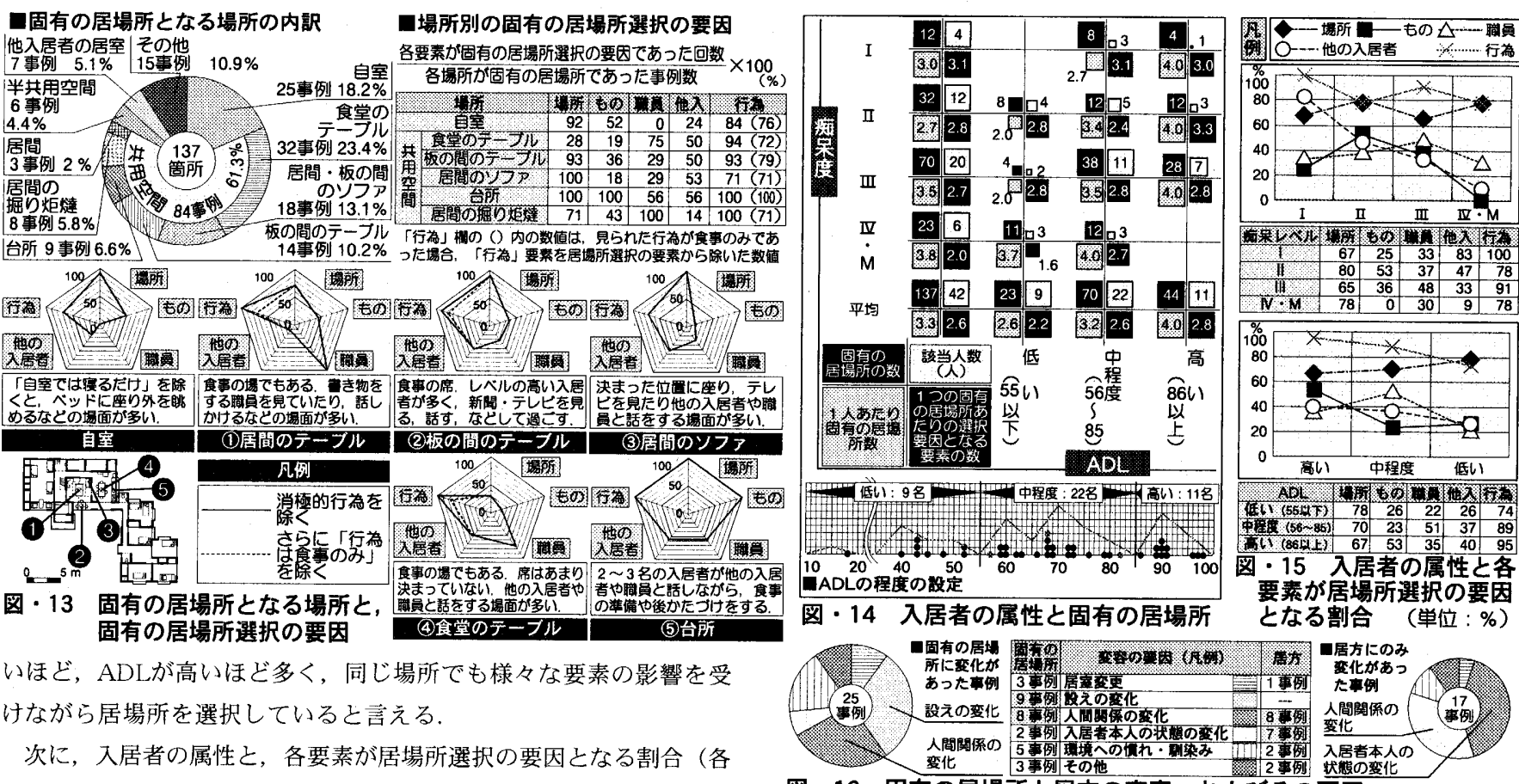

いほど，ADLが高いほど多く，同じ場所でも様々な要素の影響を受 けながら居場所を選択していると言える。

次に, 入居者の属性之, 各要素が居場所選択の要因となる割合（各 要素が固有の居場所選択の要因であった数/各属性に該当する入居者 の固有の居場所の総数）の相関を見る（図・15）と，痴呆の進行や ADLの低下によって選択要因となる割合が下がる要素も，そうでな い要素もあることが分かる。「他の入居者」は痴呆が重いと居場所選 択の要因となる割合が明らかに下がっており，痴呆が谁むにつれ他者 之関わりを持つことが困難になることを示すと思われる，「場所・行 為」は，ADLや痴呆の程度によらず，全体として固有の居場所選択 の要因となる割合が高い，全体的な傎向として，決まった場所に定位 する現象が見られ，場所に対する意識の強さが認められる。「行為」 は特にADLが高いほぞこの割合が高く, ADLの低下によって目的の ある行為が減り，先述のように他の入居者との会話が減ることも影響 して「無為」の状態が増えることが確認できる。「場所」はADLが 低いほど居場所選択の要因となる割合が若干高いが，これにはADL が低い入居者が一度定位した場所からあまり動かないことが影響して いる，相対的にみて，「もの」は湤呆四・正のときに，「職員」は痴 呆・ADLともに中程度のとき，居場所選択の要因となる割合が高 い，疬呆II・III入居者にとつて，ものがあるから座る，ものについ て他の入居者や職員と会話する，職員がいるから座る，など，ものや 職員をきっかけとして居場所が選択されていると読みとれる゙122．

5. 固有の居場所とその選択要因の変容

5. 1 固有の居場所とそこでの居方の変容 入居が長期に渡る入 居者の固有の居場所には，数や場所，之の場所での居方に変化が見ら れた．変化の見られたケースは，1）2時点を比較できたのべ20名 のうち19名，2）同じく継続比較の後の時点で抽出された居場所の べ81事例のうち，固有の居場所の琵失又は新たな獲得の事例が 25 事 例，3）同じく前後で居場所自体に変化はないものの居方が変化して いた事例が17事例，である. 固有の居場所や居方の変化の要因とし て, (1)居室変更, (2)設えの変化, (3)他の入居者の入退居やADLの低 下，痴呆の進行などによる人間関係の変化，(4)入居者本人のADL低 下や痴呆の進行，体調不良など，(5)GHの環境への慣机・馴染み，が 挙げられる，以下，それぞれの要因について事例を挙げて考察する. (1)居室の変更 Sy00 $\rightarrow 01, S y 01 \rightarrow 02$ では居室が変わった。新し

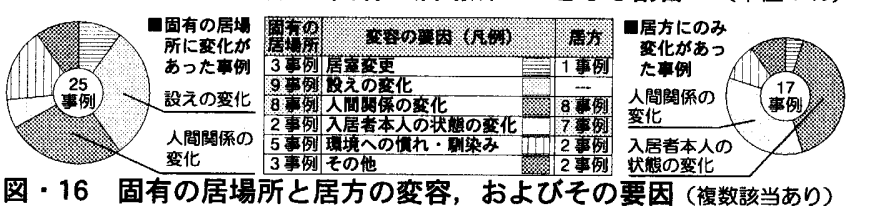

い自室を認識しつつも以前の自室で眠ってしまったり，“自室に他の 人がいる” と感じるためか「他の入居者の居室」を回って “誰か来て いないか’確認していた．また居室では眠るだけだったが, ベッドに 腰掛け空の外や板の間の様子を眺めるようになった. Skto0 $\rightarrow 01$ は, 居空変更があったが固有の居場所は変化しなかった．この居室変更は 居室(1)から(2)への，連続した居室内での移動だったためと思われる. (2)設えの変化 Sy02 $\rightarrow 03$ では, ソファ位置の変更によりソファへ の滞在が減った．また板の間のテーブルがなくなり食事の席が減った ため, Sy03の食事の席はそれまでの食堂のテーブルから居間の掘り 炬燵に変わった。この影響もあって，Sy03，04は食堂のテーブル， ソファへの滞在が減り，居間の掘り炬熢が新たに固有の居場所となっ た，同様に，Ws02 $\rightarrow 03$ も食事の際に居間の掘り炬燵に誘導されるよ うになり, 食事の時以外でも滞在する新たな固有の居場所となった。 これらのことは, 歩行が自立し自分の居場所を自分で選択できる入居 者にとっても食事の際などの睵員による日常的な誘導が入居者の固有 の居場所形成の一因となっていることを示していると思われる.

(3)人間関係の変化 Nn03 $\rightarrow 04$ では, 食堂のテーブルを継続して固 有の居場所としているが，仲がよくいつも会話していた入居者が退居 してしまい，食堂のテーブルで他の入居者とあまり会話をしなくなつ

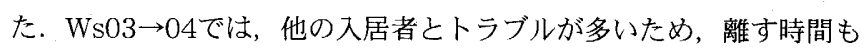
作ろうとの職員の誘導も影響して共用空間の滞在がやや減り，居室

(2)a）に続く縁側のソファを新たに固有の居場所とした. このよう に入居者同士の相性を考慮し，トラブルを避けるために職員が入居者 の居場所の誘導を行い，それが固有の居場所の選択や棲み分けのきつ かけとなる様子も観察された：また 3 章で報告したとおり人的環境は 常に変化しているが，入居者によっては他者と距離を置くことで人的 環境を一定に保ち, 固有の居場所や居方に変化のない事例もある.

(4)入居者本人の状態の変化 Um $\mathrm{Um} 00 \rightarrow 01,01 \rightarrow 02$ では, 体調不良 により自室から出ることが減り，新聞やテレビを見ていた板の間の テーブルでも寝ていることが增え同席のKtとの会話は滅った。一方 で，ADLの低下や痴呆の進行は固有の居場所を䘫失させるだけでは 
ない.Hy03０40゙は，居室でしていた手紙書きが 1 人では困難に なったが，新たに固有の居場所とした居間の掘り炬燵で職員や周囲の 様子を見ながら，安心して書き物をするようになった.

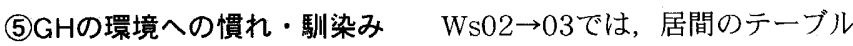
が前年に改修されて掘り炬燵になったことに慣れ，新たに固有の居場

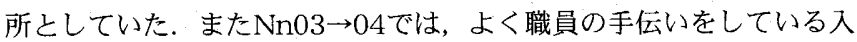
居者と馴染み, 自らも食事の片づけを手伝うことが日課になった

5. 2 固有の居場所と居方の変容の要因 固有の居場所と居方の 変容の要因を見ると, 固有の居場所の変容の要因では設えの変化と人 間関係の変化, 居方の変容の要因では人間関係の変化と入居者本人の 属性の変化が他の要因に比して多い（図・16）。このことから, 人 間関係は固有の居場所とそこでの居方のいずれにも非常に強く影響し ていると言える．また，ADLの低下や痴呆の進行などは居方には強 い影響を及ぼしているが，固有の居場所の選択にはあまり影響を与え ない. 入居者がある状態のときに獲得した固有の居場所は, その後入 居者の状態が変わってもその他の環境要素に変化がなければ固有の居 場所として継続しうることを意味すると思われる.

\section{6. まとめ}

本稿では，3章で $\mathrm{GH}$ 開設以来の $\mathrm{GH}$ の物理的・人的環境の変化を まとめ, 4 章で入居者の固有の居場所とその選択要因, 入居者の属性 との相関について分析した. また，5章で固有の居場所と居方の経時 的な変容とその要因を分析した．以下に本稿で得られた知見を示す。

1) 入居期間には幅があるが, 入居者は平均 1 年半弱で退居し, 入居 者のADL・痴呆度は次第に低下する部(3)。当該GHには長期的な看護 の困難さなどの物理的・運営的な事情があり, 体調不良, 精神不安 定，車いすの使用が必要であることなどが退居の理由となる.

2 ）入居者の入退居やADL・痴朵度の変化によって，GH内の人間関 係は常に変化すると同時に, 居室変更が生じる,

3）入居者は，個々の入居者にとって他の場所よりも意味深い「固有 の居場所」を持つ．固有の居場所となる場所は共用空間が多いが，そ れぞれの場所は，異なる環境要素の影響により固有の居場所として選 択されている。「好きなりファがある」「仲の良い入居者が居る」 「職員の姿が見える」などの環境要素が固有の居場所選択の要因に なっている実際の場面が観察されたことから、こうした居場所選択の 手がかりとなりうる要素の構築・配置が必要であると思われる.

4) 固有の居場所の数はADLが高いほど多い傾向がある. 固有の居 場所選択の要因数は, 痴呆が軽いほど, ADLが高いほど多く, 同じ 場所でも様々な要素を意識しつつ居場所を選択していると言える.

5) 各要素が固有の居場所選択の要因となる割合は，入居者の痴呆度 やADLと一定の関係がある．特に，「他の入居者」は痴呆が重いほ ど居場所選択の要因となる割合が低く，「場所・行為」は痴呆度・ ADLによらず他の要素に比べ居場所選択の要因となる割合が高い.

6）長期入居者の固有の居場所やその場所での居方には変化が見られ た. この要因として, 設え, 人間関係，入居者本人の状態の変化の影 響が強いが，特に人間関係の変化は固有の居場所とそこでの居方のい ずれにも強く影響する．また，入居者の固有の居場所は，入居者の状 態が変わっても他の環境要素に変化がなければ継続しうる.

本稿では，入居者の固有の居場所の抽出, 固有の居場所の選択要因

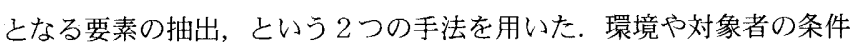
によって固有の居場所の様相や選択要因は異なると思われるが，これ
らの手法は他の環境や対象に対しても応用が可能であると考える。 註䣋

1）痴呆性老人の日常生活自立度判定基準：I・何らかの痴呆を有するが，日 常生活は家庭内及び社会的にはほぼ自立/II・日常生活に支障をきたすような 症状・行動や意志疎通の困難さが多少見られても，誰かが注意していれば自立 できる /II a・家庭内で II の症状が見られる/II b・家庭外でも II の症状が見ら れる/III・日常生活に支障をきたすような症状・行動や意志㻋通の困難さが 時々見られ，介護が必要／III a 日中を中心として III の症状が見られる／III b : 夜間を中心としてIIIの症状が見られる／V・日常生活に支障をきたすような症 状・行動や意志㻋通の困難さが頻繁に見られ，常に介護が必要/ $\mathrm{M} ・$ 判定不能 2) GHは，日本に導入された直後から急激な增加をみせている.ゴールドプラ ン 21 (2000年策定) の中で，国は 2004 年までに 3,200 籄所の $\mathrm{GH}$ を整備する ことを目標に掲げた. 2004年 5 月末現在, 目標を大きく上回る5,003簀所の $\mathrm{GH}$ が介護事業者に登録されている(独立行政法人福祉医療機構調べ)。

3）参与観察調查：一般に社会学では，広義の参与観察には少なくとも次の 5 つの調查技法が含まれるとされ，本研究における参与観察調査はこれに準ずる ものである.1. 社会生活への参加, 2. 対象社会の生活の直接観察, 3. 社会生 活に関する聞き取り，4．文書資料や文物の収集と分析，5．出来事や物事に関 する感想や意味付けについてのインタビュー12!

4） Yhは入居の翌日に退居したため，以降の分析では対象から除く

5 ）痴呆性老人の日常生活自立度判定基準辣11 とBARTHAL INDEX とに拠る. BARTHAL INDEXは最高100点で, 点数が高いほどADLが高いと判断される. 6) 松原ら文131 は，会話の状況を指標として痴呆性高齢者の人間関係を捉え;グ ループリビング化（生活単位の小規模化）によって会話が活発になるとした.

7) Skt00など: 入居者の名前と調查年度を表す。

8）鈴木文惊は、“ある場所に居るということは，それ自体意味のある積極的な 行為であり，(中略）人はその行為によって，他者・社会・環境とのさまざまな 関係を認識し，自己を定位していく’とし，「ある場所に人がいる時の様子，そ のときに周囲の環境や他者ととっている関係」を「居方（いかた）上定義した 9）抽出にあたっては，以下の判断基準を用いた。（1) 場所：決まった場所を選 んでいる場合，「居場所選択の要因となっている」，食堂のテーブルにつくが席 はどこでも構わないなよ゙ゾーンは決まっているが特に席が決まっていない場 合，「選択要因となっていない」（2)もの：その場にあっても特に意識していな い場合「選択要因となっていない」（3)職員：職員の姿を見ている，話しかけ る，賗員がいないとその場所には居ない，などの場合，「選択要因となってい

る」、職員がいても関心がない場合, 「選択要因となっていない」.(1)他の入居者 他の入居者の姿を見ている，話しかける，他の入居者がいないとその場所には 居ない，などの場合，「選択要因となっている」，他の入居者が一緒に居合わせ ても，会話がない，視線のやりとりがないなど関心がないと判断される場合， 「選択要因とないていない!．また特に，「他の入居者が居ないこと」が居場所選 択の要因となる場合もある. (5) 行為: 目的のある行為をしている場合,「選択 要因となつている」，ぼんやり眺める，寝る，などの消榭的行為を除く。

10）当然生じうる「固有の居場所」であり他の多くの入居者之共通するため, 㿍 呆やADLの程度で比較する際，結果が不明膫になる恐执があると判断した

11）半共用空間：縁側，空き居室など居室の延長として使われる共用空間。

12）石井就》は，GHに扔ける入居者の生活行動は，|ひと」や「もの」に引 きつけら机るように発生している，と表現している。

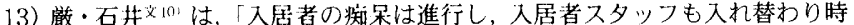
間とともに変容していくのがグループホームである」とし, ある GHの 4 年間 の経緯について，入居者，痴呆度，グループのバランスなどに変化があったと 述べており，GHにおけるこうした変化は一般的なことであると考えられる.

\section{参考文献}

1) 外山義 編著, グループホーム読本，ミネルゲァ書房，2000.3

2) 小松大記・山崎俊裕，グループホームの建築的対応の現状に関する実態調

查, 日本建築学会大会学術講演梗概集, E-1, pp429-430, 1999.9

3）林悦子・小滝一正・林玉子・他，痴呆性老人グループホームの建築形態と 空間構成，日本建築学会大会学術講演梗概集，E-1，pp255-256，2000.9

4) 石井敏, 生活行動に影響を与无る環境構成要素に関する研究, 東京大学学 位論文, 2001.3

5) 厳爽,「なじぬ」の過程における痴呆性高齢者の構築環境に関する研究, 東 京大学学位論文, 2001.3

6 ) 石井敏・外山義・長澤泰, グループホームにおける生活構成と空間利用の 特性, 日本建築学会計画系論文集第 502 号, pp103-110，1997.12

7) 石井敏・厳爽・外山義・楺弘志・長澤泰，先進事例に見る共用空間の構成 と生活の関わり，日本建築学会計画系論文集第 524号, pp 109-115, 1999.10 8) 笪爽・石井敏・他，グループホームに抢ける空間利用の時系列的変化に関 する考察，日本建築学会計画系論文集第 523 号, pp155-161，1999.9

9）石井敏・長澤泰, 生活行動に影響を与える環境構成要素痴呆性高齢者のため のグループホームに関する研究(その 2 )計画系論文集第553号, pp123-129, 2002.3 10) 厳爽・石井敏, 継続的な視点からみた痴呆性高㱓者グループホームの環境と その変容に関する研究, 日本建築学会計画系論文集第569号, pp55-62, 2003.7 11) 拙著，痴呆性高齢者グループホームにおける居住者による固有の居場所の 選択とその要因，日本建築学会計画系論文集第 556 号, pp145-152, 2002.6 12）佐藤郁哉, フィールドワークー書を持って街へ出よう, 新曜社, 1992.3 13）松原茂樹・他, 会話状況からみる痴呆性高齢者の交流の変容に関する考察, 日本建築学会計画系論文集第 545 号, pp137-142, 2001.7

14) 鈴木毅, 連載人の「居方」からの環境デザイン, 建築技術, 1993.7 1995.12 